\title{
HUBUNGAN KECENDERUNGAN TINGGAL DENGAN KECUKUPAN HUNIAN, KEPUASAN DAN KEMAMPUAN PENGHUNI RUSUNA (STUDI KASUS RUSUNA TAMBORA)
}

\author{
Jonie Rumimper ${ }^{1}$ \\ 1) Magister Teknik Perencanaan, Universitas Tarumanagara, Jakarta \\ Email: jonie.dtr@gmail.com
}

\begin{abstract}
ABSTRAK
Rusun Tambora pertama kali dibangun pada tahun 1984 yang merupakan hunian vertikal sewa bagi MBR di Jakarta dengan luas unit $21 \mathrm{~m} 2$. Dalam perkembangannya sebagian blok telah beralih menjadi hunian milik. Pada tahun 2014 sebagian blok pada Rusun Tambora dilakukan revitalisasi dengan pembangunan kembali dengan luas unit 36m2 dan berbagai fasilitas pendukung yang lebih baik. Saat ini, Rusun Tambora memiliki 3 karakteristik yang berbeda, yaitu Rusunami dan Rusunawa Lama yang sudah berusia 33 tahun dengan kualitas dan kapasitas relatif rendah serta Rusunawa Revitalisasi yang baru berusia 3 tahun dengan kualitas dan kapasitas relatif lebih baik. Penelitian ini bertujuan untuk mengetahui perbandingan kecukupan hunian, kepuasan penghuni dan kemampuan penghuni antara ketiga rusun di Tambora serta bagaimana hubungannya dengan kecenderungan tinggal. Hasil analisis komparatif memperlihatkan bahwa terdapat perbedaan signifikan kecukupan hunian, kepuasan dan kemampuan penghuni serta kecenderungan untuk tinggal antara ketiga rusun di Tambora. Hasil analisis korelasi memperlihatkan bahwa kecukupan hunian berhubungan signifikan dengan 7 variabel kondisi keluarga dan kondisi hunian, adapun kemampuan penghuni berhubungan signifikan dengan 5 variabel sosial ekonomi keluarga, sedangkan kecenderungan untuk tinggal berhubungan signifikan dengan 2 variabel kecukupan hunian dan kepuasan penghuni.
\end{abstract}

Kata kunci: kecukupan hunian, kemampuan, kepuasan, kecenderungan tinggal.

\section{PENDAHULUAN}

Rumah merupakan salah satu kebutuhan dasar (basic needs) manusia, selain pangan dan sandang. Rumah memiliki fungsi sosial budaya, yaitu sebagai sarana untuk 'memanusiakan' manusia, memberi ketenteraman hidup dan menjadi pusat kegiatan budaya manusia (Budihardjo, 1998, dalam Nurhadi, 2004). Rumah juga memiliki fungsi ekonomi, dimana memiliki rumah berarti memiliki investasi jangka panjang (Yudohusodo, 1991, dalam Nurhadi, 2004). Selain itu rumah juga memiliki fungsi politik, karena rumah merupakan salah satu unsur pokok kesejahteraan rakyat, yang seyogyanya bisa dipenuhi untuk seluruh masyarakat secara adil dan merata. Adanya perbedaan kesempatan dalam memiliki rumah dapat menimbulkan keresahan politik (Herlianto, 1986, dalam Nurhadi 2004).

Kondisi yang ada saat ini adalah ketersediaan lahan di perkotaan terbatas, sedangkan permintaan akan rumah semakin meningkat seiring dengan pertambahan jumlah penduduk. Sebagai upaya pemenuhan kebutuhan akan rumah, khususnya rumah bagi masyarakat berpenghasilan rendah, pemerintah memiliki program pembangunan rumah susun sederhana, baik sewa maupun milik. Hunian vertikal dalam bentuk Rusun dianggap menjadi salah satu solusi perumahan di kawasan perkotaan (urban).

Rusun Tambora dibangun pada tahun 1984, yang berarti saat ini bangunan tersebut sudah cukup tua berusia sekitar 33 tahun. Pada awal pengembangannya, Rusun Tambora dibagi menjadi Rusunami dan Rusunawa. Rusun Tambora dikembangkan pada lahan seluas $21.743 \mathrm{~m} 2$, dengan 
3 tower untuk Rusunami dan 4 tower untuk Rusunawa. Kesemua tower Rusunami dan Rusunawa awalnya dikembangkan sebanyak 6 lantai.

Rusun Tambora dikembangkan dengan tipe hunian $21 \mathrm{~m} 2$. Pada saat itu standar tipe $21 \mathrm{~m} 2$ memang masih lazim digunakan dalam pengembangan hunian sederhana. Namun demikian, dengan merujuk pada standar hunian per kapita sebesar $9 \mathrm{~m} 2$ per orang, maka luas unit $21 \mathrm{~m} 2$ sebenarnya hanya cukup untuk hunian 2 orang (lajang atau pasangan). Padahal kenyataannya, hunian di Rusun Tambora dihuni oleh keluarga tunggal, bahkan dalam perkembangannya pada Rusun Tambora sudah mulai dihuni oleh keluarga jamak ( 2 hingga $3 \mathrm{KK}$ ) dengan anggota antara 4 hingga 10 orang.

Pada tahun 2014, Pemerintah Provinsi DKI Jakarta telah melakukan revitalisasi sebagian Rusunawa Tambora. Hal ini dilakukan pada 2 tower Rusunawa dalam rangka peningkatan kapasitas dan kualitas fisik hunian. Dalam proses revitalisasi, pengelola Rusunawa melakukan pendataan pada semua penghuni dan diminta untuk mencari sendiri hunian sementara. Setelah proses revitalisasi selesai dilakukan, pengelola Rusunawa menghubungi para penghuni untuk dapat kembali menghuni Rusunawa yang telah direvitalisasi.

Saat ini Rusun Tambora terbagi atas 3 karakteristik, yaitu Rusunami, Rusunawa Lama, dan Rusunawa Revitalisasi. Ketiga karakteristik rusun tersebut memperlihatkan perbedaan kondisi penghuni dan kondisi hunian. Antara Rusunami dengan Rusunawa Lama terdapat perbedaan kepemilikan (milik dan sewa), kondisi sosek penghuni (non-MBR dan MBR) dan pengeluaran keluarga (tanpa sewa hunian dan adanya biaya sewa hunian). Antara Rusunami dengan Rusunawa Revitalisasi terdapat perbedaan kepemilikan, kondisi sosek penghuni, kondisi fisik hunian (bangunan lama dan bangunan baru) serta pengeluaran keluarga. Antara Rusunawa Lama dengan Rusunawa Revitalisasi terdapat perbedaan kondisi hunian dan besarnya biaya sewa (Rp. 113.000/bulan hingga Rp. 251.000/bulan dan Rp 113.000/bulan hingga Rp. 251.000/bulan).

Dari perbedaan karakteristik ketiga Rusun Tambora tersebut, Rusunami, Rusunawa Lama, dan Rusunawa Revitalisasi memiliki isunya masing-masing. Fenomena yang ada memperlihatkan bahwa terdapat isu kecukupan hunian terkait kuantitas hunian yang diindikasi kurang, kepuasan penghuni terkait kualitas hunian yang diindikasi rendah dan kemampuan penghuni yang rendah karena termasuk kategori MBR. Fenomena pada Rusun Tambora yang menarik adalah kecenderungan penghuni untuk tinggal walaupun kecukupan hunian kurang dan kepuasan penghuni rendah, sehingga faktor sewa yang murah (disubsidi) diindikasi menjadi pertimbangan utama.

Tujuan penelitian ini adalah untuk mengkaji bagaimana kondisi kecukupan hunian, kepuasan penghuni dan kemampuan penghuni Rusun di Tambora serta bagaimana hubungannya dengan kecenderungan untuk tinggal penghuni Rusun Tambora, yang dibedakan atas Rusunami, Rusunawa Lama dan Rusunawa Revitalisasi. Berdasarkan uraian permasalahan di atas, maka dapat dirumuskan pertanyaan penelitian sebagai berikut:

\footnotetext{
1. Bagaimana kondisi kecukupan hunian, kepuasan penghuni dan kemampuan penghuni Rusun Tambora?

2. Bagaimana kecenderungan tinggal penghuni Rusun Tambora?

3. Bagaimana hubungan antara kecenderungan untuk tinggal dengan kecukupan hunian, kepuasan penghuni dan kemampuan penghuni untuk pindah?
} 
Manfaat penelitian ini diharapkan dapat memberikan gambaran kecukupan hunian, kepuasan penghuni, dan kemampuan penghuni serta kecenderungan tinggal penghuni pada Rusun Tambora. Selanjutnya temuan tersebut dapat merekomendasikan hal-hal yang perlu diperhatikan dalam pengembangan Rusun yang dapat memenuhi kecukupan hunian dan kepuasan penghuni. Selain itu secara teoritis penelitian ini diharapkan dapat berkontribusi dalam menguji teori kecukupan hunian, kepuasan penghuni dan kecenderungan tinggal.

\section{BAHAN DAN METODE}

Konsep hunian yang cukup atau kecukupan hunian (housing adequacy) telah didefinisikan dan diinterpretasikan dengan cara yang berbeda oleh para peneliti dan penulis. Hunian yang cukup berarti lingkungan perumahan, baik secara kuantitatif dan kualitatif mencukupi dalam memenuhi kebutuhan, harapan dan aspirasi penghuninya. ${ }^{1}$ Oladapo (2006) serta Eggers dan Moumen (2013) fokus pada aspek kualitatif dari kecukupan hunian, yang berkaitan dengan kelayakhunian, kesehatan dan persyaratan keselamatan dari hunian. Oleh karena itu, kecukupan hunian menggambarkan lingkungan hunian yang layak huni dan mempromosikan kondisi hidup sehat, aman dan jaminan kondisi kehidupan serta kesejahteraan ekonomi dan budaya dari individu, rumah tangga dan masyarakat. ${ }^{2}$

Teori kepuasan berasal dari teori perbedaan (discrepancy theory) yang dikembangkan oleh Porter (1961). Dari teori itu Oliver (1981) mengembangkan paradigma diskonfirmasi harapan, yang menyatakan bahwa jika kinerja melebihi harapan, pelanggan akan terdiskonfirmasi secara positif (puas), sedangkan jika kinerja tidak memenuhi harapan, pelanggan akan terdiskonfirmasi secara negatif (tidak puas). ${ }^{2}$ Dalam konteks perumahan, Galster (1987) mendefinisikan kepuasan penghuni sebagai kesenjangan yang dirasakan antara kebutuhan dan aspirasi seorang responden dengan konteks realitas hunian saat ini. Selanjutnya Kepuasan penghuni meliputi kepuasan terhadap unit hunian dan kepuasan dengan lingkungan dan daerah (Onibokun, 1974). ${ }^{5}$ Ketidakpuasan akan menimbulkan kecenderungan untuk menghapus ketidakcukupan, dimana keluarga akan memilih alternatif perilaku penyesuaian, yaitu pindah ke tempat tinggal baru, atau mengubah atau menambah hunian saat ini (Morris \& Winter, 1981). ${ }^{3}$

Teori kemampuan penghuni didasarkan pada teori keterjangkauan hunian (housing affordability). Dalam pengertian yang paling komprehensif, istilah keterjangkauan hunian didefinisikan sebagai rasio pengeluaran perumahan terhadap pendapatan rumah tangga dalam periode waktu tertentu (misalnya bulanan atau tahunan). Istilah keterjangkauan murni atau keterjangkauan hunian sama sekali tidak ada artinya jika subjek tidak didefinisikan secara jelas. Jawaban yang paling umum untuk pertanyaan ini adalah terjangkau untuk rumah tangga. Definisi subjek yang paling umum dalam konteks keterjangkauan adalah rumah tangga (keluarga). Oleh karena itu subyek

\footnotetext{
${ }^{1}$ Eziyi Offia Ibem, Oluwole Ajala Alagbe , (2015) Investigating dimensions of housing adequacy evaluation by residents in public housing: Factor analysis approach, Facilities, Vol. 33 Iss: 7/8, pp.465 - 484

2 Jaafar, M., et al. (2005). The determinants of housing satisfaction level: A study on residential development project by Penang Development Corporation(PDC). Jurnal Kemanusiaan, Bil 06 Desember, 1-20.

${ }^{3}$ Salim, A. (1998). Owner-occupiers Transformation of Public Low Cost Housing in Peninsular Malaysia. Thesis Report Submitted to Newcastle University.
} 
keterjangkauan didasarkan klasifikasi rumah tangga berdasarkan tingkat pendapatan dan pengeluaran yang secara statistik mendefinisikan kelompok sosial ekonomi. ${ }^{4}$

Teori kecenderungan tinggal (propensity to stay) prinsipnya didasarkan pada model mobilitas hunian, yang salah satunya dikembangkan oleh Rossi (1955). Mobilitas dari setiap individu yang berpindah bukan peristiwa acak tetapi ditentukan oleh kebutuhan, ketidakpuasan, dan aspirasi rumah tangga (Rossi, 1955). Mobilitas merupakan mekanisme penyesuaian hunian bagi keluarga untuk menyesuaikan kebutuhan hunian (Rossi, 1955). Menurut Speare (1974), mobilitas merupakan respon terhadap stres perumahan yang dikonseptualisasikan sebagai ambang batas ketidakpuasan terhadap hunian, dimana sumber ketidakpuasan diidentifikasi sebagai perubahan dalam kebutuhan keluarga dari hasil perubahan ukuran keluarga, perubahan lingkungan sosial dan fisik dari lokasi akibat kerusakan lingkungan, atau perubahan standar keluarga akibat mobilitas sosial atau aspirasi sosial. Diprediksi bahwa rumah tangga yang sangat puas dengan perumahan mereka tidak akan mempertimbangkan pindah sementara rumah tangga tidak puas akan mempertimbangkan pindah. ${ }^{5}$

Berdasarkan hasil tinjauan teoritis yang dilakukan, dapat dirumuskan konstruksi teoritis yang menjadi fokus penelitian sebagai berikut.

\begin{tabular}{|c|c|c|c|}
\hline \multicolumn{4}{|c|}{ Analisis Komparatif-Perbandingan Variabel Antar Ke-3 Rusun di Tambora } \\
\hline Kondisi Penghuni & \multirow{2}{*}{\multicolumn{2}{|c|}{$\begin{array}{l}\text { Analisis } \\
\text { Korelasi \#1 }\end{array}$}} & \multirow[b]{4}{*}{$\rightarrow \quad \begin{array}{c}\text { Variabel Kecenderungan } \\
\text { Untuk Tinggl }\end{array}$} \\
\hline - Status kepala keluarga & & & \\
\hline - Usia kepala keluarga & & Variabel Kecukupan Hunian & \\
\hline $\begin{array}{l}\text { - Ukuran keluarga } \\
\text { - Kepemilikan Hunian } \\
\text { - Lama Tinggal }\end{array}$ & & $\begin{array}{l}\text { - Persepsi Kecukupan Luas Hunian } \\
\text { - Persepsi Kecukupan Kamar } \\
\text { - Persepsi Kecukupan Ruang lain }\end{array}$ & \\
\hline & & & \multirow{5}{*}{$\begin{array}{l}\text { - Tidak Ingin Tinggal, } \\
\text { Ingin Pindah } \\
\text { - Tidak Ingin Tinggal, } \\
\text { Sudah Rencana Pindah }\end{array}$} \\
\hline Kondisi Hunian & & Variabel Kepuasan Penghuni & \\
\hline $\begin{array}{ll}\text { - } & \text { Luas Hunian } \\
\text { - } & \text { Jumlah Kamar } \\
\text { - } & \text { Ketersediaan Ruang Lain }\end{array}$ & & $\begin{array}{l}\text { - Kepuasan Terhadap Hunian } \\
\text { - Kepuasan Terhadap Lokasi } \\
\text { - Kepuasan Terhadap Lingkungan }\end{array}$ & \\
\hline Kondisi Sosek Penghuni & \multirow{2}{*}{$\begin{array}{c}\text { Analisis } \\
\text { Korelasi } \\
\# 2\end{array}$} & Variabel Kemampuan Penghuni & \\
\hline $\begin{array}{l}\text { - Pendidikan kepala keluarga } \\
\text { - Pekerjaan kepala keluarga } \\
\text { - } \text { - Paktu tempuh ke tempat kerja } \\
\text { - Penerja dalam keluarga } \\
\text { - Pendapatan keluarga } \\
\text { - Pengeluaran keluarga }\end{array}$ & & $\begin{array}{ll}\text { - } & \text { Mampu Pindah ke Hunian Lain } \\
\text { - } & \text { Tidak Mampu Pindah ke Hunian } \\
\text { Lain }\end{array}$ & \\
\hline
\end{tabular}

Gambar 1. Konstruksi Teoritis

Penelitian dilakukan dengan pendekatan kuantitatif, yaitu termasuk dalam bentuk penelitian survei deskriptif. Berdasarkan konstruksi teoritis, maka variabel penelitian meliputi 3 variabel kecukupan hunian, 9 variabel kepuasan penghuni, 1 variabel kemampuan penghuni dan 1 variabel kecenderungan tinggal.. Adapun hipotesis penelitian dirumuskan sebagai berikut:

- Hipotesis 1, yaitu: ada perbedaan yang signifikan antara variabel kondisi penghuni, kondisi sosial ekonomi penghuni, kecukupan hunian, kepuasan penghuni, kemampuan

\footnotetext{
${ }^{4}$ Liias, R. (2002). Housing Affordability: Theoretical Approaches and Practical Implementation. Book Article on Challenges and Opportunities in Housing: New Concepts, Policies and Initiatives. In-House Publishing: Rotterdam.

${ }^{5}$ Rossi, P. (1955). Why Families Move: A Study In The Social Psychology Of Urban Residential Mobility. Illinois: Free Press.
} 
penghuni dan kecenderungan untuk tinggal pada Rusunami, Rusunawa Lama dan Rusunawa Revitalisasi.

- Hipotesis 2, yaitu: ada hubungan (korelasi) antara kondisi penghuni dan kondisi hunian dengan kecukupan hunian.

- Hipotesis 3, yaitu: ada hubungan (korelasi) antara kondisi sosial ekonomi penghuni dengan kemampuan penghuni untuk pindah ke hunian lain.

- Hipotesis 4, yaitu: ada hubungan (korelasi) antara kecukupan hunian, kepuasan penghuni, dan kemampuan penghuni dengan kecenderungan untuk tinggal.

Sampel penelitian ditentukan sebesar 150 keluarga penghuni Rusun Tambora yang dipilih menggunakan metode proportionate random sampling dengan pendekatan proporsional pada Rusunami, Rusunawa Lama dan Rusunawa Revitalisasi. Metode analisis kuantitatif dipilih 2 metode, yaitu analisis komparatif untuk membandingkan ketiga Rusun di Tambora dan analisis korelasi untuk melihat hubungan antar variabel sesuai konstruksi teoritis.

\section{HASIL DAN PEMBAHASAN}

Dari hasil pendataan lapangan, diketahui bahwa responden didominasi perempuan berusia produktif (20-60 tahun) yang berstatus sebagai istri. Hal ini disebabkan karena survei dilakukan saat hari kerja, sehingga kepala keluarga umumnya tidak berada di rumah karena sedang ada aktivitas di luar rumah. Karakteristik keluarga, diketahui bahwa penghuni umumnya merupakan keluarga dengan ukuran 3-6 orang. Kepala keluarga umumnya berusia produktif dengan pendidikan SMA dan bekerja sebagai karyawan atau wirausaha.

Kondisi kecukupan hunian relatif sangat rendah pada rusun di Tambora yang berusia lama, namun sangat tinggi pada rusun yang telah direvitalisasi. Hal ini dapat dipahami karena rusun yang baru direvitalisasi memiliki kualitas yang jauh lebih baik dibandingkan rusun yang lama. Kondisi kecukupan hunian pada ketiga rusun di Tambora terbukti memiliki perbedaan yang signifikan, yaitu:

- Terkait kecukupan luas hunian sebagian besar penghuni Rusunawa Lama $(54,17 \%)$ dan Rusunami (62\%) merasa tidak cukup dengan luas hunian yang ada saat ini, sedangkan pada Rusunawa Revitalisasi hampir seluruh (96\%) penghuni merasa cukup dengan luas hunian saat ini.

- Terkait kecukupan jumlah kamar sebagian besar penghuni Rusunami (72\%) dan sebagian penghuni Rusunawa Lama $(39,58 \%)$ merasa tidak cukup dengan jumlah kamar yang ada saat ini, sedangkan pada Rusunawa Revitalisasi hampir seluruh $(96 \%)$ penghuni merasa cukup dengan jumlah kamar saat ini.

- Terkait kecukupan ketersediaan ruang lain sebagian besar penghuni Rusunami (89\%) dan sebagian penghuni Rusunawa Lama $(37,59 \%)$ merasa tidak cukup dengan jumlah kamar yang ada saat ini, sedangkan pada Rusunawa Revitalisasi seluruh (100\%) penghuni merasa cukup dengan ruang lain tersedia.

Kondisi kecukupan hunian yang relatif sangat rendah pada rusun di Tambora yang sudah lama menjadi permasalahan yang perlu diselesaikan Pemerintah Provinsi DKI Jakarta dalam rangka menyediakan hunian yang layak huni bagi masyarakat. Sedangkan kecukupan hunian yang relatif sangat tinggi pada rusun di Tambora yang baru direvitalisasi dapat menjadi rujukan bagi program revitalisasi rusun lama di DKI Jakarta dan perlu dijaga agar tidak semakin menurun. 
Berdasarkan analisis korelasi, diketahui bahwa kecukupan hunian terbukti memiliki hubungan yang signifikan dengan status pernikahan kepala keluarga (-), jumlah anggota keluarga serumah $(-)$, status kepemilikan hunian (+), lama tinggal (-), luas hunian $(+)$, jumlah kamar $(+)$, dan ketersediaan ruang lain (+). Faktor-faktor tersebut perlu menjadi pertimbangan bagi Pemerintah DKI Jakarta dan Pengelola Rusunawa dalam proses penghunian di rusunawa, agar setiap keluarga dapat menghuni unit hunian dengan yang sesuai dengan kondisi keluarga masingmasing.

Kondisi kepuasan penghuni pada rusun di Tambora ternyata tidak sama dengan kondisi kecukupan hunian, dimana tingkat kepuasan penghuni pada ketiga rusun di Tambora relatif cukup tinggi. Hal ini diindikasi karena penghuni sebagai MBR memiliki toleransi lebih baik terhadap kualitas fisik yang ada serta persepsi kepuasan yang agaknya terpengaruhi harga sewa rusun yang murah (akibat subsidi). Dari 8 variabel kepuasan penghuni, 6 variabel kepuasan penghuni relatif tidak berbeda dari ketiga rusun, dimana hampir semua penghuni merasa puas terhadap kualitas hunian $(83,11 \%)$, terhadap utilitas rusun $(93,92 \%)$, terhadap fasilitas rusun $(83,11 \%)$, terhadap nilai strategis lokasi $(97,30 \%)$, terhadap kemudahan pencapaian lokasi $(98,65 \%)$, dan terhadap keamanan lingkungan $(89,19 \%)$. Hal ini memperlihatkan bahwa semua penghuni memiliki kepuasan yang sama pada kondisi hunian, utilitas, fasilitas dan lokasi, karena ketiganya berada dalam 1 kompleks yang sama sehingga memiliki persepsi/penilaian yang sama.

Sedangkan hanya 2 variabel yang memiliki perbedaan dari ketiga rusun, dimana kepuasan terhadap kebersihan lingkungan pada Rusunami relatif lebih kecil (40\%) dibanding pada Rusunawa Revitalisasi (98\%) dan Rusunawa Lama (81,25\%), serta kepuasan terhadap keasrian lingkungan pada Rusunawa Revitalisasi jauh lebih besar (98\%) dibanding pada Rusunami (54\%) dan Rusunawa Lama (75\%).

Kondisi kemampuan penghuni untuk pindah ke hunian yang lebih baik relatif sangat kecil pada ketiga rusun di Tambora. Hal ini dapat dipahami mengingat penghuni merupakan MBR dengan pekerjaan informal, penghasilan kecil dan tidak menentu, namun di sisi lain biaya hunian tanpa subsidi di Jakarta relatif tidak terjangkau. Berdasarkan hasil analisis komparatif, terbukti bahwa terdapat perbedaan kemampuan penghuni untuk pindah. Perbedaan terlihat pada penghuni Rusunami, dimana ada sebagian kecil (2\%) yang menyatakan memiliki kemampuan untuk pindah ke hunian yang lebih baik. Sedangkan penghuni Rusunawa Lama dan Rusunawa Revitalisasi seluruhnya (100\%) menyatakan tidak mampu untuk pindah ke hunian yang lebih baik.

Berdasarkan analisis korelasi, diketahui bahwa kemampuan penghuni untuk pindah ke hunian yang lebih baik terbukti memiliki hubungan yang signifikan dengan tingkat pendidikan kepala keluarga (+), anggota keluarga lain serumah yang bekerja (+), waktu tempuh ke tempat kerja (-), penghasilan keluarga (+), dan pengeluaran keluarga (+). Hasil ini dapat menjadi masukan bagi Pemerintah DKI Jakarta dan Pengelola Rusunawa untuk dapat meningkatkan faktor-faktor sosial ekonomi penghuni melalui penyediaan program kegiatan produktif penghuni rusunawa yang dapat meningkatkan kemampuan penghuni. Selain itu, Pengelola Rusunawa perlu senantiasa mendata faktor-faktor sosial ekonomi penghuni tersebut, sebagai pertimbangan kemampuan penghuni untuk pindah ke hunian yang lebih baik. 
Kondisi kecenderungan penghuni untuk tinggal (tidak pindah) di Rusun Tambora relatif tinggi. Berdasarkan hasil analisis komparatif diketahui bahwa terdapat perbedaan yang signifikan kecenderungan penghuni untuk tinggal antara ketiga Rusun di Tambora. Perbedaan terlihat pada Rusunawa Revitalisasi, dimana hampir seluruh penghuni $(96,83 \%)$ menyatakan ingin tinggal (tidak pindah). Sedangkan hampir sepertiga penghuni pada Rusunami (32\%) dan lebih dari seperempat penghuni pada Rusunawa Lama $(27,65 \%)$ menyatakan memiliki keinginan untuk pindah, dan bahkan sebagian kecil sudah merencanakan untuk pindah. Hal ini memperlihatkan bahwa pada rusun yang baru direvitalisasi kecenderungan untuk tinggal jauh lebih besar dibanding pada rusun yang lama.

Berdasarkan analisis korelasi, diketahui bahwa kecenderungan untuk tinggal terbukti memiliki hubungan yang signifikan dengan kecukupan hunian (+), dan kepuasan terhadap kebersihan lingkungan $(+)$. Hal ini memperlihatkan bahwa hunian yang cukup dan lingkungan yang bersih meningkatkan kecenderungan penghuni untuk tinggal. Oleh karena itu, upaya untuk meningkatkan kecukupan hunian melalui program revitalisasi rusunawa lama akan mendukung keberhasilan program penghunian rusunawa di Jakarta.

\section{KESIMPULAN}

Terdapat perbedaan signifikan antara ketiga Rusun di Tambora, yaitu Rusunami, Rusunawa Lama dan Rusunawa Revitalisasi. Data yang diperbandingkan meliputi kondisi keluarga, status penghunian, kondisi sosial ekonomi keluarga, kondisi hunian, kecukupan hunian, kepuasan penghuni, kemampuan untuk pindah ke hunian lain, dan kecenderungan untuk tinggal.

Kecukupan hunian terbukti memiliki hubungan signifikan dengan kondisi keluarga dan kondisi hunian, yaitu status pernikahan kepala keluarga, jumlah anggota keluarga serumah, status kepemilikan hunian, lama tinggal, luas hunian, jumlah kamar, dan ketersediaan ruang lain. Terdapat 1 variabel yang tidak terbukti memiliki hubungan yang signifikan dengan kecukupan hunian, yaitu variabel usia kepala keluarga. Hal ini memperlihatkan bahwa usia kepala keluarga tidak menentukan status pernikahan dan jumlah anggota keluarga sehingga tidak berhubungan secara signifikan dengan kecukupan hunian. Ada penghuni yang berusia tua namun hidup sendiri, di sisi lain ada juga yang berusia muda namun sudah berkeluarga dengan ukuran keluarga besar.

Kemampuan penghuni terbukti memiliki hubungan signifikan dengan kondisi sosial ekonomi keluarga, yaitu tingkat pendidikan kepala keluarga, anggota keluarga lain serumah yang bekerja, waktu tempuh ke tempat kerja, total penghasilan keluarga, dan total pengeluaran keluarga. Terdapat 1 variabel yang tidak terbukti memiliki hubungan yang signifikan dengan kecukupan hunian, yaitu variabel pekerjaan kepala keluarga. Hal ini memperlihatkan bahwa pekerjaan kepala keluarga tidak menentukan besarnya penghasilan keluarga sehingga tidak berhubungan secara signifikan dengan kemampuan keluarga. Ada penghuni yang bekerja di sektor informal namun berpenghasilan besar, di sisi lain ada juga yang bekerja di sektor formal namun sudah berpenghasilan kecil.

Kecenderungan untuk tinggal terbukti memiliki hubungan signifikan dengan kecukupan, dan kepuasan terhadap kebersihan lingkungan. Terdapat 8 variabel yang tidak terbukti memiliki hubungan yang signifikan dengan kecenderungan untuk tinggal, yaitu kemampuan untuk pindah, 
kepuasan terhadap kualitas hunian, kepuasan terhadap utilitas yang disediakan, kepuasan terhadap fasilitas yang disediakan, kepuasan terhadap nilai strategis lokasi, kepuasan terhadap kemudahan pencapaian lokasi, kepuasan terhadap keamanan lingkungan, dan kepuasan terhadap keasrian lingkungan. Artinya, walaupun sebagian penghuni mengaku mampu untuk pindah, tidak puas dengan hunian, lingkungan, dan lokasi, namun mereka masih memilih untuk tinggal (tidak pindah). Hal ini diindikasi karena adanya program subsidi diberikan Pemerintah Provinsi DKI Jakarta kepada penghuni Rusunawa di Tambora dan tidak ada ketentuan apabila secara ekonomi sudah mampu diwajibkan pindah, maka membuat penghuni cenderung nyaman tinggal karena biaya sewa yang murah sehingga memilih tinggal (tidak pindah) walaupun secara kemampuan sudah memadai.

\section{REFERENSI}

Ibem, E., \& Alagbe, O. (2015). Investigating Dimensions Of Housing Adequacy Evaluation By Residents In Public Housing: Factor Analysis Approach. Facilities, 33(7/8), 465-484.

Jaafar, M., et al. (2005). The determinants of housing satisfaction level: A study on residential development project by Penang Development Corporation(PDC). Jurnal Kemanusiaan, Bil 06 Desember, 1-20.

Liias, R. (2002). Housing Affordability: Theoretical Approaches and Practical Implementation. In Book Article on Challenges and Opportunities in Housing: New Concepts, Policies and Initiatives. Rotterdam: In-House Publishing.

Nurhadi, I. (2004). Preferensi Masyarakat Dalam Memilih Perumahan Perkotaan di Kota Tangerang (Studi Kasus: Perumahan Banjar Wijaya, Poris Indah, dan Perumnas IV). Tesis Program Magister. Semarang: Program Pasca Sarjana, Magister Teknik Pembangunan Kota, Universitas Diponegoro.

Rossi, P. (1955). Why Families Move: A Study In The Social Psychology Of Urban Residential Mobility. Illinois: Free Press.

Salim, A. (1998). Owner-occupiers Transformation of Public Low Cost Housing in Peninsular Malaysia. Thesis Report Submitted to Newcastle University. 